\begin{tabular}{|l|l|l||}
\hline \multicolumn{2}{|c|}{ PublisherInfo } \\
\hline \hline PublisherName & $:$ & BioMed Central \\
\hline \hline PublisherLocation & $:$ & London \\
\hline \hline PublisherImprintName & $:$ & BioMed Central \\
\hline \hline
\end{tabular}

\title{
Retroviruses reinfect humans
}

\begin{tabular}{|l|l|l||}
\hline \multicolumn{2}{|c|}{ ArticleInfo } \\
\hline \hline ArticleID & $:$ & 4927 \\
\hline \hline ArticleDOI & $:$ & $10.1186 /$ gb-spotlight-20040324-01 \\
\hline \hline ArticleCitationID & $:$ & spotlight-20040324-01 \\
\hline \hline ArticleSequenceNumber & $:$ & 279 \\
\hline \hline ArticleCategory & $:$ & Research news \\
\hline ArticleFirstPage & $:$ & 1 \\
\hline \hline ArticleLastPage & $:$ & 3 \\
\hline \hline & & RegistrationDate : 2004-3-24 \\
\hline ArticleHistory & $:$ & OnlineDate \\
\hline \hline ArticleCopyright & $:$ & BioMed Central Ltd2004-3-24 \\
\hline \hline ArticleGrants & $:$ & \\
\hline \hline ArticleContext & $:$ & 130594411 \\
\hline \hline
\end{tabular}




\section{Cathy Holding}

Email: cathyholding@aol.com

There are 98,000 human endogenous retroviral (HERV) sequences in the human genome, most inactivated by mutations. A new study in the March 22 Proceedings of the National Academy of Sciences reveals that this large number of insertions is most likely the result of germline reinfection rather than retrotransposition or complementation.

"What we think is really happening is that in the past 30 million years, there have been very many of these elements, not fixed but just present in a small number of individuals," said Robert Belshaw, from the Department of Biological Sciences, Imperial College London, and lead author of the study.

These would have been infecting and moving about, possibly between individuals, but certainly within individuals, from somatic cells back into germline cells. Periodically, one would pick up a mutation that would stop it from moving about. "Once dead, there would be no selection against it from the host. They're just a bit of junk, and they could then drift to fixation by chance," Belshaw told us.

"The idea which some people had held was that a lot of these elements, although they come originally from viruses, had actually spread around the genome by mechanisms other than virological ones," said John M. Coffin, professor of molecular biology and microbiology at Tufts University's Sackler School of Graduate Biomedical Sciences

Investigating the most recently active family, HERV-K (HML2), Belshaw and colleagues report that endogenous viral sequences in the genome comprise dead viruses that have drifted to fixation by chance and represent fallout from a 30-million year-old persistent infection by retroviral elements. They used data mining techniques to reconstruct the ratio of nonsynonymous to synonymous changes $(d \mathrm{~N} / d \mathrm{~S})$, and the acquisition of stop codons, during the evolution of HERV-K (HML2). The team showed that all genes have been under continuous purifying selection.

"Purifying selection is the selection against mutations that arise because they confer some disadvantage to the organism or virus or whatever carries them," said Coffin, who the journal lists as an editor of the paper. In every round of replication, a number of mutations will appear, and if deleterious, that virus will be selected against, so that the population remains 'pure.'

"This means that these genes must have been important in the process by which they are moved from one part of the genome to another, suggesting that there has been an important role in replication," said Coffin, who was not involved in the study. The evidence for purifying selection implies that viral replication "wasn't by intracellular odd-ball gene rearrangement mechanisms," he said.

"These HERVs are present in all of us, and clinicians and scientists are trying to associate these viruses with particular diseases," said Paul N. Nelson from the Department of Biomedical Science at Warwick University. He added that the problem has been that when molecular techniques are used to detect the virus, apparently "everybody's got them."

Nelson, who was not involved in the study, suggests that the work shows that there is an opportunity for these viruses to proliferate within an individual. "That means that some individuals may have higher levels, or more numbers, of these viruses than others. That's an important finding, because it's this 
individuality that I think is the key thing," he said. HERV-K has been implicated in rheumatologic diseases, and this factor could then account for particular HRVs being associated with disease, he told us.

"You've got a large population process going on. Periodically, one of the dead products gets fixed in the genome, and we've inferred it all from these dead products. What's really going on is, I think, more interesting. It's not simply a few copying events of elements within germline cells," said Belshaw.

\section{References}

1. Proceedings of the National Academy of Sciences USA, [http://www.pnas.org/]

2. Robert Belshaw, [http://www.bio.ic.ac.uk/dept/welcome.htm]

3. John M. Coffin, [http://www.tufts.edu/sackler/facultyIntros/coffinJ.html]

4. Many human endogenous retrovirus K (HERV-K) proviruses are unique to humans.

5. Paul N. Nelson, [http://www.wlv.ac.uk/science/biomedical/]

This PDF file was created after publication. 